\title{
Epithelial thymic tumours in paediatric age: a report from the TREP project
}

\author{
Elena Carretto ${ }^{1 *}$, Alessandro Inserra ${ }^{2}$, Andrea Ferrari $^{3}$, Massimo Conte ${ }^{4}$, Andrea Di Cataldo ${ }^{5}$, Roberta Migliorati ${ }^{6}$, \\ Giovanni Cecchetto ${ }^{1}$ and Gianni Bisogno ${ }^{7}$
}

\begin{abstract}
Background: Thymic epithelial tumours (thymoma and carcinoma) are exceptionally rare in children. We describe a national multicentre series with a view to illustrating their clinical behaviour and the results of treatment.

Methods: From January 2000 all patients under 18 years of age diagnosed with "rare paediatric tumours" were centrally registered by the Italian centres participating in the TREP project (Tumori Rari in Età Pediatrica [Rare Tumours in Paediatric Age]). The clinical data of children with a thymic epithelial tumour registered as at December 2009 were analyzed for the purposes of the present study.

Results: Our series comprised 4 patients with thymoma and 5 with carcinoma (4 males, 5 females; median age 12.4 years). The tumour masses were mainly large, exceeding $5 \mathrm{~cm}$ in largest diameter. Based on the Masaoka staging system, 3 patients were stage I, 1 was stage III, 1 was stage IVa and 4 were stage IVb.

All 3 patients with stage I thymoma underwent complete tumour resection at diagnosis and were alive 22, 35 and 93 months after surgery. One patient with a thymoma metastasizing to the kidneys died rapidly due to respiratory failure.

Thymic carcinomas were much more aggressive, infiltrating nearby organs (in 4 cases) and regional nodes (in 5), and spreading to the bone (in 3) and liver (in 1). All patients received multidrug chemotherapy (platinum derivatives + etoposide or other drugs) with evidence of tumour reduction in 3 cases. Two patients underwent partial tumour resection (after chemo-radiotherapy in one case) and 4 patients were given radiotherapy (45-54 Gy). All patients died of their disease.
\end{abstract}

Conclusions: Children with thymomas completely resected at diagnosis have an excellent prognosis while thymic carcinomas behave aggressively and carry a poor prognosis despite multimodal treatment.

\section{Background}

Primary thymic epithelial neoplasms, thymomas and thymic carcinomas, are uncommon tumours with an annual incidence of approximately 1-5 per million population [1]. Their aetiology is still largely unknown, but thymoma has been reported in association with multiple endocrine neoplasia syndrome type 1 (MEN1) and autoimmune disorders [2].

Thymoma is classified in two main types, depending on whether the neoplastic epithelial cells and their nuclei are uniformly bland (type A thymoma) or have a predominantly round or polygonal appearance (type B)

\footnotetext{
* Correspondence: elena.carretto@unipd.it

'Division of Paediatric Surgery, Department of Paediatrics, Padova University Hospital, Padova, Italy

Full list of author information is available at the end of the article
}

[3]. Type B thymomas are further divided into three subtypes according to the extent of lymphocytic infiltrate and the degree of atypia of the neoplastic epithelial cells, i.e. B1 (richest in lymphocytes), B2, and B3 (richest in epithelial cells). Thymomas combining type A with B1-like or (rarely) B2-like features are designated type $\mathrm{AB}$.

Thymic carcinomas are termed according to their differentiation (squamous cell, muco-epidermoid, etc.) [1].

In adults, the main histological subtypes in most published series are type B2 and AB thymomas (with 20$35 \%$ of all cases each) [4]. The percentage of thymic carcinomas is reportedly about $10-25 \%$ [5].

These tumours show variable clinical behaviour ranging from a tendency to be indolent and non-invasive to highly infiltrative tumours with metastatic spread to the

\section{Biomed Central}


pericardium and pleura and, occasionally, to the lung [6].

Thymic tumours are exceptionally rare in the paediatric age group, accounting for less than $1 \%$ of childhood mediastinal tumours [7]. As in adults, thymic tumours in children may be asymptomatic or present with compressive symptoms. They are classified and staged in the same way as adult tumours but there are very few reports on the treatment of thymic tumours in children.

With a view to promoting research on, and improving the clinical management of very rare paediatric cancers (childhood solid malignancies characterised by an annual incidence $<2 /$ million and not considered in other clinical trials) a nationwide cooperative initiative called the TREP project (Tumori Rari in Età Pediatrica [Rare Tumours in Paediatric Age]) was launched in Italy in $2000[8,9]$. Thymic tumours were included in this project and here we describe the clinical features, treatment and outcome of the TREP series patients with this diagnosis.

\section{Methods}

All patients under 18 years of age with a diagnosis of "rare paediatric tumours" were centrally registered from 1 January 2000 onwards by all the Italian centres participating in the TREP project. The present study focuses on the clinical data recorded for 9 children with a histologically confirmed diagnosis of epithelial tumour of the thymus treated between January 2000 and December 2009. The series included 4 males and 5 females, with a median age of 12.4 years (range $4.8-16.3$ years).

\section{TREP diagnostic and therapeutic recommendations}

Guidelines were developed to help paediatric oncologists diagnose thymic tumours. After chest X-ray, computed tomography $(\mathrm{CT})$ and/or magnetic resonance imaging (MRI) were recommended to assess local tumour extent. A bone marrow biopsy was part of the diagnostic workup to rule out lymphatic neoplasms. Surgical guidelines suggested that primary excision should be attempted via a sternotomy if non-mutilating, and complete resection was considered feasible; if not, a biopsy was to be taken for diagnostic purposes. The criteria adopted for diagnosing thymoma or thymic carcinoma were as stated by the WHO classification. Tumours were staged according to the commonly-used Masaoka staging system [10] (Table 1). The distinction between tymoma and thymic carcinoma was based on the local pathology report. In addition 5 cases were reviewed by the TREP Pathology Panel and no discrepancies with the local diagnosis were noted.

The paucity of data in the literature prevented us from establishing a strict protocol, but radiotherapy and chemotherapy were recommended in an attempt to reduce

\section{Table 1 Thymoma staging according to Masaoka et al.} [10]

\begin{tabular}{ll}
\hline Stage I & Totally encapsulated \\
\hline Stage II & $\begin{array}{l}\text { Capsular invasion and/or invasion into surrounding fat or } \\
\text { pleura }\end{array}$ \\
\hline Stage III & Invasion into organs (pericardium, lung, great vessels) \\
\hline Stage IV-A & Pleural or pericardial implants \\
\hline Stage IV-B & Haematogenous metastases \\
\hline
\end{tabular}

the tumour mass and make delayed surgery feasible. The guidelines stated that the most often used multidrug regimens included cisplatin, doxorubicin, vincristine and cyclophosphamide.

\section{Results}

Patients

The patients' demographic data are shown in Table 2. Eight children in our series were symptomatic, pain being the most frequent symptom (in 5 patients). Compression of the respiratory tract by the mediastinal tumour caused chronic coughing in 2 patients and dyspnoea in 2 (with airway compression and coma in 1). General symptoms (fatigue, fever, weight loss) were observed in 5 patients. One child had 2 paraneoplastic autoimmune syndromes (systemic lupus erythematosus and hypertrophic pulmonary osteoarthropathy). In one asymptomatic child, the tumour was diagnosed incidentally, after a radiological assessment for scoliosis.

The tumour masses were generally large at diagnosis, exceeding $5 \mathrm{~cm}$ in largest diameter in 7 cases (and more than $10 \mathrm{~cm}$ in 4 of them).

The thymic carcinomas revealed a very aggressive behaviour with infiltration of adjacent organs (in 4 cases), regional lymph node invasion (in 5) and metastases to the bone (in 3) and liver (in 1). One child with thymoma had distant metastases to both kidneys.

According to the Masaoka staging system, 3 patients were classified as stage I, 1 as stage III, 1 as stage IVa and 4 as stage IVb.

\section{Treatment}

A complete primary resection was performed at diagnosis in 3 patients with stage I thymoma, involving a sternotomy in 2 cases and a left thoracotomy in one.

In one child, the histopathological diagnosis of thymoma was established on autopsy after a rapid death due to respiratory failure resulting from compression of the respiratory tract by an unrecognized mediastinal tumour.

Among the 5 patients with carcinoma, a tumour resection was attempted in two (after chemo-radiotherapy in one), but left macroscopic residual disease; a biopsy of the enlarged regional lymph nodes was performed for 
Table 2 Clinical characteristics and treatment

\begin{tabular}{|c|c|c|c|c|c|c|c|c|c|c|c|c|}
\hline $\bar{N}$ & Tumour type & $\begin{array}{l}\begin{array}{l}\text { Age } \\
\text { (years) }\end{array} \\
\end{array}$ & Stage & Symptoms & $\begin{array}{l}\text { Size } \\
(\mathrm{cm})\end{array}$ & $\begin{array}{l}\text { Local } \\
\text { extent }\end{array}$ & $\begin{array}{l}\text { Lymph } \\
\text { nodes }\end{array}$ & Metastasis & Surgery & CT & $\begin{array}{l}\text { RT } \\
\text { (Gy) }\end{array}$ & $\begin{array}{l}\text { Outcome/ } \\
\text { FU (m) }\end{array}$ \\
\hline$\overline{1}$ & Thymoma B1 & 4.8 & 1 & Cough & $\begin{array}{l}>5 \mathrm{e} \\
<10\end{array}$ & no & no & no & $\begin{array}{l}\text { Complete } \\
\text { resection at } \\
\text { diagnosis }\end{array}$ & No & No & $1^{\circ} \mathrm{CR} / 35.2$ \\
\hline 2 & Thymoma B1 & 12.4 & $\mathrm{IVb}$ & $\begin{array}{l}\text { Dyspnoea, } \\
\text { coma }\end{array}$ & & & & $\begin{array}{l}\text { Kidney, } \\
\text { bilaterally }\end{array}$ & No & $\mathrm{No}$ & No & Died \\
\hline 3 & Thymoma B1 & 11.4 & 1 & $\begin{array}{l}\text { Incidental } \\
\text { (radiography } \\
\text { for scoliosis) }\end{array}$ & $4 \times 2.5 \times 2$ & no & no & no & $\begin{array}{l}\text { Complete } \\
\text { resection at } \\
\text { diagnosis }\end{array}$ & No & No & $1^{\circ} \mathrm{CR} / 93.40$ \\
\hline$\overline{4}$ & Thymoma $\mathrm{AB}$ & 15 & 1 & $\begin{array}{l}\text { Chest pain, } \\
\text { fever }\end{array}$ & $16 \times 8 \times 14$ & no & no & no & $\begin{array}{l}\text { Complete } \\
\text { resection at } \\
\text { diagnosis }\end{array}$ & No & No & $1^{\circ} \mathrm{CR} / 21.7$ \\
\hline 5 & $\begin{array}{l}\text { Lympho- } \\
\text { epithelioma-like } \\
\text { carcinoma }\end{array}$ & 11.7 & III & $\begin{array}{l}\text { Chest pain, } \\
\text { joint pain, } \\
\text { fever, } \\
\text { butterfly } \\
\text { rash, digital } \\
\text { clubbing }\end{array}$ & $12 \times 9 \times 6$ & $\begin{array}{l}\text { Lung, } \\
\text { lymph } \\
\text { node }\end{array}$ & Mediastinal & no & $\begin{array}{l}\text { Incomplete } \\
\text { resection at } \\
\text { diagnosis }\end{array}$ & $\begin{array}{l}\text { Ifo-VCR } \\
+ \text { ACT (1 } \\
\text { cycle) } \\
\text { CDDP } \\
\text { +VP16 (2 } \\
\text { cycles) }\end{array}$ & 50 & Died/12 \\
\hline 6 & $\begin{array}{l}\text { Carcinoma with } \\
\text { neuroendocrine } \\
\text { differentiation }\end{array}$ & 15.5 & $\mathrm{IVb}$ & $\begin{array}{l}\text { Shoulder } \\
\text { pain }\end{array}$ & $10 \times 6 \times 12$ & $\begin{array}{l}\text { Sternum, } \\
\text { pleural/ } \\
\text { pericardial } \\
\text { effusion }\end{array}$ & $\begin{array}{l}\text { Latero- } \\
\text { cervical, } \\
\text { mediastinal }\end{array}$ & Bone & $\begin{array}{l}\text { Lymph node } \\
\text { biopsy at } \\
\text { diagnosis }\end{array}$ & $\begin{array}{l}\text { CDDP+ } \\
\text { VP16 (7 } \\
\text { cycles) }\end{array}$ & Yes & Died/17 \\
\hline 7 & $\begin{array}{l}\text { Poorly } \\
\text { differentiated } \\
\text { carcinoma }\end{array}$ & 14.7 & $\mathrm{IVb}$ & $\begin{array}{l}\text { Fever, } \\
\text { vomiting, } \\
\text { weight loss, } \\
\text { abdominal } \\
\text { and chest } \\
\text { pain }\end{array}$ & $>5$ & Lung & Mediastinal & Bone & $\begin{array}{l}\text { Lymph node } \\
\text { biopsy at } \\
\text { diagnosis }\end{array}$ & $\begin{array}{l}\text { CDDP+5FU } \\
(1 \text { cycle) } \\
\text { CDDP } \\
+ \text { ADR+VCR } \\
+ \text { CPM (5 } \\
\text { cycles) }\end{array}$ & 45 & Died/10 \\
\hline 8 & $\begin{array}{l}\text { Poorly } \\
\text { differentiated } \\
\text { carcinoma }\end{array}$ & 16.3 & $\mathrm{IVb}$ & $\begin{array}{l}\text { Cough, fever, } \\
\text { fatigue, back } \\
\text { pain }\end{array}$ & $\begin{array}{l}>5 \mathrm{e} \\
<10\end{array}$ & no & $\begin{array}{l}\text { Latero- } \\
\text { cervical }\end{array}$ & Liver, bone & $\begin{array}{l}\text { Lymph node } \\
\text { biopsy at } \\
\text { diagnosis }\end{array}$ & $\begin{array}{l}\text { CDDP } \\
+ \text { CPM } \\
+ \text { ADR (4 } \\
\text { cycle) }\end{array}$ & No & Died/7 \\
\hline$\overline{9}$ & $\begin{array}{l}\text { Lympho- } \\
\text { epithelioma-like } \\
\text { carcinoma }\end{array}$ & 12 & $\mathrm{IVa}$ & $\begin{array}{l}\text { Fatigue, } \\
\text { weight loss, } \\
\text { dyspnoea }\end{array}$ & $10 \times 10$ & $\begin{array}{l}\text { Pleural } \\
\text { nodes and } \\
\text { effusion }\end{array}$ & $\begin{array}{l}\text { Left hylar, } \\
\text { mediastinal }\end{array}$ & no & $\begin{array}{l}\text { Incomplete } \\
\text { resection after } \\
\text { chemotherapy }\end{array}$ & $\begin{array}{l}\text { CDDP+5FU } \\
\text { (4 cycles) } \\
\text { CDDP (6 } \\
\text { cycle) }\end{array}$ & 54 & Died/16 \\
\hline
\end{tabular}

IFO = Ifosfamide, VCR = Vincristine, ACT = Actinomycin, CDDP = Cisplatin, VP16 = Etoposide, 5FU = Fluorouracil, CPM = Cyclophosphamide, ADR = Adriamycin, $\mathrm{CT}=$ chemotherapy, $\mathrm{RT}=$ radiotherapy, $\mathrm{FU}=$ follow-up (months), $1^{\circ} \mathrm{CR}=$ first complete remission

diagnostic purposes in 3 cases. All received multidrug chemotherapy based on platinum derivatives in association with etoposide ( 2 cases) or other drugs. A tumour volume reduction was evident in three cases (see table: $\mathrm{N} \mathrm{6,8}$ and 9), ranging from $25 \%$ to $66 \%$, but the response was shortlived (1 to 3 months).

Radiotherapy to the mediastinal region was administered in 4 patients, in doses ranging from 45 to 54 Gy.

\section{Outcome}

The disease progressed in all 5 patients with carcinoma, who died from 7 to 17 months after its diagnosis. One child with thymoma also died soon after being admitted to hospital due to compression of the respiratory tract by the tumour mass. The 3 patients with stage I thymoma were alive with no evidence of disease 22,35 and 93 months after complete tumour excision.

\section{Discussion}

Our report confirms that thymic tumours are very uncommon in the paediatric age group.

In adults, the clinical behaviour of thymic tumours may vary from an indolent course to a very aggressive one. The WHO classification describes subtypes with a progressively worsening prognosis: thymoma types $\mathrm{A}$, $\mathrm{AB}$, and $\mathrm{B} 1$ have a relatively good outcome; $\mathrm{B} 2$ and $\mathrm{B} 3$ are more aggressive and have intermediate survival rates, while thymic carcinoma carries the worst prognosis [3].

For thymomas, the WHO histological classification and the Masaoka staging system are independent prognostic factors. Based on the Masaoka staging system, the 20 -year survival rates are reportedly $89 \%, 91 \%, 49 \%, 0 \%$, and $0 \%$ in patients with Stages I, II, III, IVa, and IVb disease, respectively [11]. 
Surgical resection is the mainstay of treatment for patients presenting with Masaoka Stage I or II disease; complete tumour resection is accompanied by complete thymectomy, the removal of all surrounding mediastinal fat and possibly also the pleura, to increase the chances of ensuring negative surgical margins [12].

Patients achieving a complete resection of a stage I tumour have a 5 -year survival rate of $100 \%$ and a recurrence rate of $1 \%$ [13]; these patients are not considered candidates for adjuvant therapies.

Our limited experience suggests that thymomas in children have a similar behaviour with stage I thymoma having a favourable outcome. No further treatment was necessary in our cases after tumour removal. Conversely, the child with stage IV thymoma died of disease even before any therapy could be attempted.

Published experiences of paediatric thymoma are limited, but report similar results: In agreement with our results, Dhall [14] reported on 2 cases of thymoma (Masaoka stage I) treated with complete resection: both patients were still disease-free 3 years after surgery. Liang [15] reported on 2 cases of thymoma and provided a comprehensive review and analysis of paediatric cases reported in the past 30 years (32 cases in all): among 17 patients with stage I and II tumours, 16/17 patients (94\%) were alive when their case was published (with a followup ranging from 3 months to 9 years), whereas only 3 of 9 patients (33\%) with stage IV disease survived.

In adults, thymic carcinomas have a more aggressive clinical course than thymomas and they are associated with a poor prognosis. They are frequently not amenable to radical resection at diagnosis so multimodal therapies (including neo-adjuvant or adjuvant chemo-radiotherapy) are employed. Overall, the results obtained in adults with thymic carcinoma are unsatisfactory, with a reported 5-year survival rate of around $50 \%$ and a mean survival of 2.5 years $[13,16,17]$. Subgroup analysis has revealed a significant difference in survival rates between patients achieving total versus subtotal resections, and between totally resected and inoperable groups. The survival rate also differed significantly between patients receiving radio-chemotherapy and those receiving radiotherapy alone, and between the former and those given no adjuvant therapy [13].

Igawa [18] conducted a retrospective study on the efficacy and safety of combined CBDCA (carboplatin) + paclitaxel therapy in 11 previously-untreated patients with unresectable advanced thymic carcinomas: the overall median survival time was 22.7 months and the 1 -year survival rate was $62 \%$.

Studies describing children with thymic carcinoma are scarce. Yaris [19] reviewed the English literature and described 15 cases under 18 years of age, most of whom presented with an anterior mediastinal mass and suffered from chest pain, cough, fever, weight loss, and respiratory distress. Radiologically, these tumours were often associated with pleural effusions and/or the involvement of neighbouring structures such as the pleura and pericardium. Nine patients died ( 8 of them with metastatic disease) within 1.5 to 15 months of their diagnosis, 4 were alive ( 2 of them without disease) from 1 to 12 years after their diagnosis.

A recent report from the Polish Rare Tumour group [20] described 9 children with thymic carcinomas: 2 were classified as Masaoka stage II, 5 as stage III, and 2 as stage IV. Only 1 patient underwent complete tumour resection at diagnosis, six received multidrug chemotherapy and 4 had radiotherapy. The outcome was dismal, and only 2 children were long-term survivors.

The cases of thymic carcinoma in our series all had unfavourable features: they all presented with large masses and evidence of local or distant spread. Only a diagnostic biopsy was performed in 3 patients and an attempt at tumour resection in 2 left macroscopic residuals. Despite the administration of chemotherapy and radiotherapy, these tumours remained unresectable and all patients died.

Four patients in our series received radiotherapy, but it failed to reduce the tumour bulk. In the series published by the Polish group, 4 children were irradiated and 2 of them (with stage II and stage III disease) were still alive, though one of them unfortunately developed severe neurological sequelae due to radiation-induced spinal damage.

Although thymic tumours seem to be sensitive to chemotherapy, the most effective regimen remains to be established. Different drug combinations have been used, generally based on cisplatin, doxorubicin, cyclophosphamide and prednisone [21].

In our experience, we only found evidence of a shortlived tumour response in 3 children treated with cisplatin based chemotherapy. Similar results were obtained by the Polish group, with 4 out of 5 assessable children showing a tumour response after initial chemotherapy. Different regimens were administered, however, making it hard to say which is the most effective combination [20].

More effective drugs are therefore needed and targeted molecular therapies might pave the way to new therapeutic options in patients with thymic carcinoma in advanced stages. Strobel et al. [22] described the first case of a carcinoma with an activating KIT mutation and suggested that screening for activating KIT mutations may identify KIT-expressing carcinomas that could benefit from imatinib. The same authors [23] described 4 patients of metastatic thymic carcinoma refractory to conventional therapies who were treated with sunitinib, a multi-targeted tyrosine kinase inhibitor; 2 patients were still in partial remission after 14 and 18 months on sunitinib, one patient died 4 months after starting sunitinib, and the last patient was alive with stable primary 
disease and hepatic metastases, and with a partial remission of coeliac lymph node metastases.

\section{Conclusions}

Thymic tumours are very rare in the paediatric age group. Like their adult counterparts, children with thymomas that are completely resected at diagnosis have an excellent prognosis. Thymic carcinomas behave very aggressively, however, and the prognosis is poor. The TREP project has demonstrated that cooperative studies are feasible even on exceptionally rare tumours and this approach should be transferred to a more international level in an effort to establish the best treatment for these very rare tumours.

\section{Acknowledgements}

The TREP Project is partially funded by the CARIPARO (Cassa di Risparmio di Padova e Rovigo) and by the "Città della Speranza" Foundation.

Elena Carretto was financed by the CARIPARO (Cassa di Risparmio di Padova e Rovigo).

We wish to acknowledge Elisa Mancini, the TREP Project data manager, for her help.

We thank Bernadette Brennan for manuscript critical review.

Written consent to publication was obtained from patients or their relatives.

\section{Author details}

'Division of Paediatric Surgery, Department of Paediatrics, Padova University Hospital, Padova, Italy. ${ }^{2}$ Paediatric Surgery Department, IRCCS Ospedale Pediatrico Bambino Gesu', Roma, Italy. ${ }^{3}$ Paediatric Oncology Unit, Fondazione IRCCS Istituto Nazionale Tumori, Milano, Italy. ${ }^{4}$ Department of Paediatric Haematology-Oncology, Giannina Gaslini Children's Hospital, Genova, Italy. ${ }^{5}$ Department of Paediatric Haematology-Oncology, University of Catania, Catania, Italy. ${ }^{6}$ Division of Paediatric Oncology, Pausilipon Children's Hospital, Napoli, Italy. ${ }^{7}$ Haematology-Oncology Division, Department of Paediatrics, Padova University Hospital, Padova, Italy.

\section{Authors' contributions}

GB substantially contributed to the conception and design of the study and approved the final version of the manuscript.

EC and Al were involved in drafting the manuscript and critically revising its intellectual content.

GC contributed to data analysis and interpretation, and critically revised the work.

$A F, M C, A D, R M$ made substantial contributions to data acquisition.

All authors have read and approved the final manuscript.

\section{Competing interests}

The authors declare that they have no competing interests.

Received: 16 November 2010 Accepted: 21 May 2011

Published: 21 May 2011

\section{References}

1. Müller-Hermelink HK, Engel $P$, Kuo TT, Ströbel Ph, Marx A, Harris NL, Möller P, Menestrina F, Shimosato Y, Asamura H, Masaoka A, Sobin LH: World Health Organisation Histological Classification of Tumours. Tumours of the Thymus: Introduction. IARC Press, Lyon; 2004.

2. De Toma G, Plocco M, Nicolanti V, Brozzetti S, Letizia C, Cavallaro A: Type B1 thymoma in multiple endocrine neoplasia type 1 (MEN-1) syndrome. Tumouri 2001, 87:266-268.

3. Rosai J, Sobin LH: World Health Organisation Histological Classification of Tumours. Histological Typing of Tumours of the Thymus. Springer-Verlag: Berlin-Heidelberg; 21999.

4. Ho FC, Fu KH, Lam SY, Chiu SW, Chan AC, Müller-Hermelink HK: Evaluation of a histogenetic classification for thymic epithelial tumours. Histopathology 1994, 25:21-29.
5. Chalabreysse L, Roy P, Cordier JF, Loire R, Gamondes JP, Thivolet-Bejui F: Correlation of the WHO schema for the classification of thymic epithelial neoplasms with prognosis: a retrospective study of 90 tumours. Am J Surg Pathol 2002, 26:1605-1611.

6. Venuta F, Rendina EA, Coloni GF: Multimodality treatment of thymic tumours. Thorac Surg Clin 2009, 19:71-81.

7. Ramon y, Cajal S, Suster S: Primary thymic epithelial neoplasms in children. Am J Surg Pathol 1991, 15:466-474.

8. Ferrari A, Bisogno G, De Salvo GL, Indolfi P, Perilongo G, Cecchetto G, Italian Study on Rare Tumours in Paediatric Age (TREP), Associazione Italiana Ematologia Oncologia Paediatrica (AIEOP): The challenge of very rare tumours in childhood: the Italian TREP project. Eur J Cancer 2007, 43:654-659.

9. Pastore G, De Salvo GL, Bisogno G, Dama E, Inserra A, Cecchetto G, Ferrari A, TREP Group, CSD of Epidemiology Biostatistics, AIEOP: Evaluating access to paediatric cancer care centers of children and adolescents with rare tumours in Italy: the TREP project. Pediatr Blood Cancer 2009, 53:152-155.

10. Masaoka A, Monden Y, Nakahara K, Tanioka T: Follow-up study of thymomas with special reference to their clinical stages. Cancer 1981, 48:2485-2492.

11. Okumura M, Ohta M, Tateyama H, Nakagawa K, Matsumura A, Maeda H, Tada H, Eimoto T, Matsuda H, Masaoka A: The World Health Organization histologic classification system reflects the oncologic behavior of thymoma: a clinical study of 273 patients. Cancer 2002, 94:624-632.

12. Wright CD: Management of thymomas. Crit Rev Oncol Hematol 2008, 65:109-120.

13. Kondo K, Monden Y: Therapy for thymic epithelial tumours: a clinical study of 1,320 patients from Japan. Ann Thorac Surg 2003, 76:878-884, discussion 884-5

14. Dhall G, Ginsburg HB, Bodenstein L, Fefferman NR, Greco MA, Chang MW, Gardner S: Thymoma in children: report of two cases and review of literature. J Pediatr Hematol Oncol 2004, 26:681-685.

15. Liang X, Lovell MA, Capocelli KE, Albano EA, Birch S, Keating AK, Graham DK: Thymoma in children: report of 2 cases and review of the literature. Pediatr Develop Pathol 2010, 13:202-208.

16. Ríos A, Torres J, Galindo PJ, Roca MJ, Rodríguez JM, Sola J, Parrilla P: Prognostic factors in thymic epithelial neoplasms. Eur J Cardiothorac Surg 2002, 21:307-313.

17. Chung DA: Thymic carcinoma - analysis of nineteen clinicopathological studies. Thorac Cardiovasc Surg 2000, 48:114-119.

18. Igawa S, Murakami H, Takahashi T, Nakamura Y, Tsuya A, Naito T, Kaira K, Ono A, Shukuya T, Tamiya A, Endo M, Yamamoto N: Efficacy of chemotherapy with carboplatin and paclitaxel for unresectable thymic carcinoma. Lung Cancer 2010, 67:194-197.

19. Yaris N, Nas Y, Cobanoglu U, Yavuz MN: Thymic carcinoma in children. Pediatr Blood Cancer 2006, 47:224-227.

20. Stachowicz-Stencel T, Bien E, Balcerska A, Godzinski J, Synakiewicz A, Madziara W, Perek-Polnik M, Peregud-Pogorzelski J, Pietras W, Pobudejska A, Kurylak A, Mankowski P: Thymic carcinoma in children: a report from the Polish Paediatric Rare Tumours Study. Pediatr Blood Cancer 2010, 54:916-920.

21. Kim ES, Putnam JB, Komaki R, Walsh GL, Ro JY, Shin HJ, Truong M, Moon H, Swisher SG, Fossella FV, Khuri FR, Hong WK, Shin DM: Phase II study of a multidisciplinary approach with induction chemotherapy, followed by surgical resection, radiation therapy, and consolidation chemotherapy for unresectable malignant thymomas: Final report. Lung Cancer 2004, 44:369-379.

22. Ströbel $P$, Hartmann M, Jakob A, Mikesch K, Brink I, Dirnhofer S, Marx A: Thymic carcinoma with overexpression of mutated KIT and the response to imatinib. N Engl J Med 2004, 350:2625-2626.

23. Ströbel P, Bargou R, Wolff A, Spitzer D, Manegold C, DimitrakopoulouStrauss A, Strauss L, Sauer C, Mayer F, Hohenberger P, Marx A: Sunitinib in metastatic thymic carcinomas: laboratory findings and initial clinical experience. $\mathrm{Br} J$ Cancer 2010, 103:196-200.

doi:10.1186/1750-1172-6-28

Cite this article as: Carretto et al:: Epithelial thymic tumours in paediatric age: a report from the TREP project. Orphanet Journal of Rare Diseases 2011 6:28. 